\title{
DESKRIPTIF TINGKAT PENGETAHUAN IBU BEKERJA TENTANG PEMBERIAN ASI EKSLUSIF SECARA TIDAK LANGSUNG PADA BAYI DI RS IBU DAN ANAK ERIA BUNDA SUKAJADI PEKANBARU
}

\author{
Rifa Yanti ${ }^{[1]}$, Ela Ummi.I ${ }^{[2]}$ \\ [1] Staff pengajar Jurusan D III Keperawatan Fakultas MIPA dan Kesehatan Universitas Muhammadiyah \\ Riau \\ [2] Alumnus Jurusan D III Keperawatan-FMIPA UMRI \\ Email :rifaye1@ymail.com ${ }^{[1]}$
}

\begin{abstract}
ABSTRAK
ASI eklusif adalah ASI (Air Susu Ibu), yang diberikan pada bayi selama 4-6 bulan dan tanpa tambahan lain seperti susu formula, pisang, papaya, bubur, biskuit, dan nasi tim. ASI eklusif juga merupakan nutrisi terbaik pada awal usia kehidupan bayi. ASI ibarat emas yang diberikan gratis oleh Tuhan karena ASI adalah cairan hidup yang dapat menyesuaikan kandungan zatnya yang dapat memenuhi kebutuhan gizi bayi, karena mengandung semua zat gizi sesuai kebutuhan untuk pertumbuhan dan perkembangan bayi. Penelitian ini bertujuan Untuk mengetahui deskriptif tingkat pengetahuan ibu bekerja tentang pemberian ASI Eklusif secara tidak langsung pada bayi di RSIA Eria Bunda Sukajadi Pekanbaru. Penelitian ini bersifat deskriftif. Sampel dalam penelitian ini berjumlah 30 responden dengan menggunakan kuesioner, dimana pengambilan sampel dilakukan secara accidental sampling. Dari hasil penelitian yang telah dilakukan dengan judul deskriptif tingkat pengetahun ibu bekerja tentang pemberian ASI Ekslusif secara tidak langsung pada bayi, secara umum ditemukan dari 30 responden,bahwa yang berpengetahuan baik sebanyak 17 orang $(56,67 \%)$, berpengetahuan cukup sebanyak 12 orang (40\%), dan berpengetahuan kurang sebanyak 1 orang $(3,33 \%)$. Diharapkan kepada masyarakat khususnya ibu bekerja dapat lebih meningkatkan dan menerapkan pemahaman tentang pemberian ASI Ekslusif secara tidak langsung pada bayi guna meningkatkan stimulasi dan daya yahan tubuh bayi secara adekuat.
\end{abstract}

Kata Kunci: Tingkat Pengetahuan, Ibu bekerja, ASI Ekslusif .

\section{PENDAHULUAN}

Menyusui menyusui merupakan suatu proses yang alamiah dan termasuk salah satu tugas dalam perawatan kesehatan anak (bayi), namun pada kenyataannya tidak semua ibu dapat melaksanakan tugas tersebut dengan baik, dan juga tidak semua ibu berhasil menyusui bayinya dan bahkan banyak dari beberapa ibu menghentikan menyusui lebih dini. Kondisi ini tidak hanya berdampak pada kesehatan bayi tetapi juga dapat mengganggu konsep diri sebagai seorang ibu, karena tidak dapat berperan optimal dalam perawatan kesehatan bayinya. (Hamid, 2000).
Beberapa hasil penelitian menunjukkan bahwa berbagai dampak buruk dapat terjadi pada bayi bila tidak mendapat Air Susu Ibu (ASI). Berdasarkan penelitian (Lucas, 1992 dalam Masora; 2003) diketahui bahwa Intelengen Question (IQ) sekelompok bayi prematur yang diberi ASI adalah 8.5 poin lebih tinggi dibandingkan kelompok bayi yang diberikan susu formula. Selain itu kurangnya atau tidak diberikannya ASI pada bayi dapat memberikan dampak lain, baik dampak fisiologis, psikologis sampai kondisi terburuk pada bayi yaitu kematian pada bayi (Achadi, 1999; Bobak, 2000). 
Menurut hasil WHO tahun 20022003, didapati data jumlah pemberian ASI eksklusif pada bayi di bawah usia dua bulan hanya mencakup $64 \%$ dari total bayi yang ada. Persentase tersebut menurun seiring dengan bertambahnya usia bayi. Yakni, $46 \%$ pada bayi usia 2-3 bulan dan $14 \%$ pada bayi usia 4-5\% (Depkes, 2005).

Di Indonesia saat ini sekitar 50 persen anak yang lahir diberi susu formula. Sedangkan untuk Provinsi DKI Jakarta hingga Juli 2010 hanya sekitar 33 persen yang memberi ASI Eklusif dari target 80 persen di tahun 2010 ini. Pemberian susu formula meningkat tiga kali lipat dari 15,8 persen menjadi 45,5 persen, dan ini semua didukung dengan pekerjaan yang dilakukan oleh ibu bekerja. Dimana sebagian besar perusahaan di Indonesia menerapkan kebijakan pemberian cuti melahirkan hanya 3 bulan. Di Inggris ibu yang hamil dan melahirkan bisa mendapatkan cuti 40 minggu. Di Denmark, ibu mendapat cuti empat atau delapan minggu sebelum melahirkan dan 14 minggu sesudah melahirkan ditambah 10 minggu cuti untuk merawat bayi (Anonim, 2010).

Sedangkan berdasarkan survey awal yang peneliti lakukan pada tanggal 25 Maret 2011 terhadap 10 responden tentang pemberian ASI Ekslusif secara tidak langsung pada bayi didapatkan bahwa sebanyak 8 orang (80\%) ibu bekerja telah tahu tentang cara menyimpan ASI dan sebanyak 2 orang (20\%) belum mengetahui mengenai pemberian ASI.

\section{METODOLOGI PENELITIAN}

Dalam penelitian ini peneliti menggunakan metode penelitian deskriptif, yaitu suatu metode penelitian yang dilakukan dengan tujuan utama untuk membuat gambaran atau deskripsi tentang suatu keadan secara objektif (Notoatmodjo, 2002).

Penelitian ini hanya mengambarkan dan melihat gambaran pengetahuan ibu bekerja tentang pemberian ASI ekslusif secara tidak langsung pada bayi di RS Ibu dan Anak Eria Bunda sukajadi Pekanbaru.:

\section{HASIL DAN PEMBAHASAN}

Hasil penelitian yang telah dilakukan pada tanggal 25-31 Maret 2011 terhadap 30 Responden di RSIA Eria Bunda Sukajadi Pekanbaru yang berjudul deskriptif tingkat Pengetahuan Ibu Bekerja Tentang Pemberian ASI Ekslusif Pada Bayi di RSIA Eria Bunda Sukajadi Pekanbaru, dapat diuraikan pada tabel - tabel berikut :

Tabel 1: Distribusi Frekuensi Responden Berdasarkan Umur di RSIA Eria Bunda Pekanbaru Maret 2011

\begin{tabular}{|c|c|c|c|}
\hline No & Umur & Frekuensi & Persentase \\
\hline 1 & $\begin{array}{c}20-35 \\
\text { Tahun }\end{array}$ & 29 & 96,67 \\
\hline 2 & $\begin{array}{c}>35 \\
\text { Tahun }\end{array}$ & 1 & 3,33 \\
\hline & Jumlah & 30 & $100 \%$ \\
\hline
\end{tabular}

Dari hasil penelitian yang dilakukan peneliti di RSIA Eria Bunda Sukajadi Pekanbaru terhadap 30 responden, ditemukan mayoritas umur responden berusia antara 20-35 Tahun sebanyakn 29 Orang $(96,67 \%)$.

Sesuai dengan teori Saksono (2000), mengatakan bahwa umur dapat mempengaruhi pengetahuan seseorang karena semakin muda umur seseorang, semakin rendah pengetahuan dan pengalaman yang dimilikinya dan sebaliknya semakin lanjut usia seseorang maka semakin tinggi pengetahuan dan pengalaman yang dimilikinya. Tetapi bila semua itu didukung oleh faktor pendidikan yang tinggi. 
Tabel 2: Distribusi Frekuensi Responden

Berdasarkan Pendidikan di RSIA Eria

Bunda Pekanbaru Maret 2011

\begin{tabular}{|c|c|c|c|}
\hline No & Pendidikan & Frekuensi & Persentase \\
\hline 1 & SMP & 1 & 3,33 \\
\hline 2 & SMA & 8 & 26,67 \\
\hline 3 & Perguruan Tinggi & 21 & 70 \\
\hline & Jumlah & 30 & $100 \%$ \\
\hline
\end{tabular}

Faktor lain yang dapat mempengaruhi pengetahuan yaitu tingkat pendidikan. Berdasarkan dari hasil penelitian bahwa mayorita pendidikan responden berda pada jenjang pendidikan perguruan tinggi yaitu sebanyak 21 Orang $(70 \%)$.

Menurut Seroja (1999), mengatakan bahwa pendidikan seseorang merupakan faktor yang paling mempengaruhi pengetahuan seseorang. Hal yang serupa juga diungkapkan oleh Suhardi (2009), faktor - faktor yang mempengaruhi pengetahuan seseorang salah satunya adalah pendidikan. Semakin tinggi pendidikan seseorang maka semakin mudah orang tersebut menerima informasi sehingga semakin banyak pula pengetahuan yang didapatnya.

Menurut pendapat peneliti, tingkat pendidikan sangat mempengaruhi pengetahuan seseorang terhadap sesuatu, bila pendidikan tinggi maka pengetahuannya juga baik, berwawasan luas serta mampu berpikir kritis. Dan bila pendidikan redah dapat menyebabkan pengetahuan seseorang juga rendah. Hal ini akan lebih tampak jika tidak pernah memperoleh informasi tentang kesehatan.

Tabel 3: Distribusi Frekuensi Tingkat Pengetahuan Responden Tentang Pemberian ASI Ekslusif Secara Tidak Langsung pada bayi di RSIA Eria Bunda Pekanbaru Maret 2011

\begin{tabular}{|c|c|c|c|}
\hline No & $\begin{array}{c}\text { Tingkat } \\
\text { Pengetahuan }\end{array}$ & Frekuensi & Persentase \\
\hline 1 & Baik & 17 & 56,67 \\
\hline 2 & Cukup & 12 & 40 \\
\hline
\end{tabular}

\begin{tabular}{|c|c|c|c|}
\hline 3 & Kurang & 1 & 3,33 \\
\hline & Jumlah & 30 & $100 \%$ \\
\hline
\end{tabular}

secara umum dari 30 responden berada dalam kategori baik sebanyak 17 Orang (56,67\%), cukup 12 Orang (40\%), dan kurang sebanyak 1 orang $(3,33 \%)$, dan dapat disimpulkan bahwa mayoritas pengetahuan responden dalam kategori baik yaitu sebanyak 17 orang $(56,67 \%)$.

Hal ini juga didukung berdasarkan hasil penelitian yang dilakukan Arfiah (2007) di RSIA Siti Fatimah Makassar dengan judul "Gambaran Pengetahuan Ibu Post Partum Tentang Pemberian Asi Ekslusif Pada Bayi di RSIA Siti Fatimah Makassar" secara umum dari 80 responden berada dalam kategori baik sebanyak 49 orang $(61,25 \%)$ dan kurang sebanyak 31 orang $(38,75 \%)$, mayoritas tingkat pendidikan responden berada pada jenjang pendidikan peguruan tinggi sebanyak 38 Orang (47,5\%), dan mayoritas responden pernah memperoleh informasi sebanyak 64 orang $(80 \%)$.

Sedangkan menurut Wilson (2002), menyatakan bahwa pengetahuan adalah pembentukan asosiatif yang menghubungkan atau menjalin sebuah pikiran dengan kenyataan atau pikiran lain berdasarkan pengalaman yang berulang ulang tanpa pemahaman mengenai kualitas sebab dan akibat universal

\section{DAFTAR PUSTAKA}

Arikunto, S. (2006). Prosedur penelitian suatu pendekatan praktek. Jakarta: EGC

Chumbey, J. (2003). Tip Soal ASI dan Menyusui. Jakarta: Erlangga

Dahlan. (1999). Sumber informasi. Diperoleh pada tanggal 30 Maret 2011 dari http://www.sumber informasi.com 
Dahlan, (2006). Ibu Bekerja dan ASI Perah, Diperoleh tanggal 17 November 2010

http://www.ayahbunda.co.id

Danuatmaja, bonny. (2003). 40 Hari Pasca Persalinan. Jakarta: Puspa Swara

Farida. (2004). Pentingnya Memberi Lebel Pada wadah ASI Perah. Diperoleh tanggal 08 november 2010. Dari http://female.kompas.com.

Kalnins, D. (2003). Baby Feeding. Jakarta: Prestasi Pustakaraya.

Notoatmojo, S. (2002). Metodologi Penelitian Kesehatan. Jakarta : Rinne Cipta

Notoatmodjo. (2003). Pengetahuan. Jakarta : Rinne Cipta

Notoatmojo. S. (2005). Metodologi Penelitian Kesehatan. Jakarta : Rinne Cipta

Mary, MD. (2006). Tata Laksana Ibu dan Bayi Pasca Kelahiran. Jakarta: Prestasi Pustakaraya.

Mc Luhan. (1999). Informasi dan pengetahuan. Diperoleh pada tanggal 2 April 2011 dari http://www.informasi.com

Rahadian, P. (2008). Panduan Menyimpan ASI. Diperoleh pada tanggal 28 oktober 2010 dari http://www.asipasti.co.cc/2008/07/pandu an-menyimpan-asi.html

Raharmi. (2000). Informasi. Diperoleh pada tanggal 3 April 2011 dari http://www.informasi.co.id

Rober. (2000). Informasi sebagai ilmu pengetahuan. Diperoleh pada tanggal 2 April 2011 dari http://www.geogle.com

Suhardi. (2009). Faktor-faktor yang mempengaruhi pengetahuan. Diperoleh pada tanggal 3 April 2011 dari http://www.lasphast.com

Saksono, (2000). Klasifikasi Umur. Diperoleh pada tanggal 2 April 2011 dari http://www.umur.com

Seroja. (1999). Peranan pendidikan. Diperoleh pada tanggal 3 April 2011 dari http://www.pendidikan.com

Sri. (2009). Perkembangan Umur. diperoleh pada tanggal 2 April 2011 dari http://www.umur.co.id

Suryabudi, M. (1999). Cara Merawat Bayi dan Anak-anak. Bandung: Pionir Jaya

Utami, roesli. (2000). Menganal ASI Eklusif. Jakarta: Trubus Angriwidya

William, F. (2003). Pedoman Merawat Bayi. Jakarta: Erlangga

Wilson. (2002). Pemahaman dan penggetahuan. Diperoleh pada tanggal 3 April 2011 dari http://id. Wikipedia.org/wiki/pengetahuan.

Written. (2007). Menyimpan ASI Perah. Diperoleh pada tanggal 02 november 2010 dari http://www.Tips bayi.co.id. 